(c) Elsevier/INRA

Original article

\title{
Genetic variability and differentiation in roe deer (Capreolus capreolus $L$ ) of Central Europe
}

\author{
GB Hartl ${ }^{1 *}$, F Reimoser ${ }^{1}$, R Willing ${ }^{1}$, J Köller ${ }^{2}$ \\ ${ }^{1}$ Veterinärmedizinische Universität Wien, Forschungsinstitut für Wildtierkunde \\ und Ökologie, Savoyenstrasse 1, A-1160 Vienna, Austria; \\ ${ }^{2}$ University of Agricultural Sciences, Institute of Zoology and Game Biology, \\ Pater Karoly u 1, H-2103 Gödöllö, Hungary
}

(Received 21 September 1990; accepted 3 June 1991)

Summary - Two hundred and thirty-nine roe deer from 13 provenances in Hungary, Austria and Switzerland were examined for genetic variability and differentiation at 40 presumptive isoenzyme loci by means of horizontal starch gel electrophoresis. For completion, previously published data from 160 roe deer from 7 provenances in Austria were also included in the present analysis. With a total $\bar{P}$ (proportion of polymorphic loci) of $30 \%$, a mean $\bar{P}$ of $15.8 \%$ (SD $2 \%$ ) and a mean $\bar{H}$ (expected average heterozygosity of $4.9 \%$ (SD 1.2\%) Capreolus capreolus is one of the genetically most variable deer species yet studied. Relative genetic differentiation among populations was examined. About $10 \%$ of the total genetic diversity is due to genetic diversity between demes. Absolute genetic distances are typical for local populations throughout the area except in Hungary, where the $D$-values with all other provenances suggest an emerging subspecies. This differentiation may have been caused by the completely fenced borders between Austria and its neighbouring countries to the east. Except in Hungary, the pattern of allele frequencies reflects the patchy distribution of roe deer populations and periodical bottlenecking caused by the breeding behaviour and/or overhunting and recolonization, rather than a large scale geographic diversification. The various aspects of genetic variability and differentiation in roe deer are discussed in comparison to a related species with a rather different strategy of adaptation, the red deer.

roe deer / electrophoresis / isoenzymes / genetic variability / genetic distance

Résumé - Variabilité et différenciation génétiques chez le chevreuil (Capreolus capreolus $L$ ) d'Europe centrale. La variabilité et les différences génétiques à 40 locus isoenzymatiques ont été étudiés sur 239 chevreuils, en provenance de 13 régions différentes couvrant la Hongrie, l'Autriche et la Suisse, par électrophorèse horizontale sur gel d'amidon. Cette étude englobe aussi des données précédemment publiées sur 160 chevreuils en provenance

* Correspondence and reprints : Forschungsinstitut für Wildtierkunde der Veterinärmedizinischen Universität Wien, Savoyenstrasse 1, A-1160 Vienna, Austria

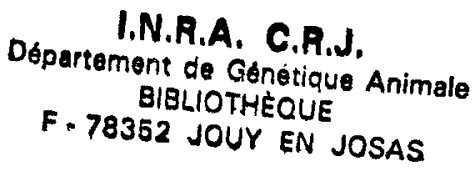


de 7 régions d'Autriche. Avec une proportion de locus polymorphes de $30 \%$ globalement et de 15,8 $\pm 2 \%$ en moyenne par origine, et un pourcentage attendu moyen d'hétérozygotie de $4,9 \pm 1,2 \%$, Capreolus capreolus est une des espèces les plus variables parmi les espèces de cervidés étudiées jusqu'à présent. Environ $10 \%$ de la diversité totale est due à la diversité génétique entre dèmes. Les distances génétiques absolues (D) sont typiques de populations locales sur l'ensemble de la zone, sauf en Hongrie, où les valeurs de D par rapport aux autres provenances suggèrent l'émergence d'une sous-espèce. Cette différenciation peut avoir été provoquée par les frontières totalement grillagées entre l'Autriche et les pays qui l'avoisinent à l'est. Sauf en Hongrie, les différences de fréquences géniques reflètent une distribution en plaques irrégulières des populations de chevreuil et des phénomènes périodiques de goulet d'étranglement dûs au comportement reproductif et/ou à des chasses excessives suivies de recolonisation, plutôt qu'à une diversification géographique à grande échelle. Les différents aspects de variabilité et de diversité génétiques chez le chevreuil sont discutés, en comparaison avec le cerf, qui est une espèce apparentée ayant une stratégie d'adaptation différente.

chevreuil / électrophorèse / isoenzymes / variabilité génétique / distance génétique

\section{INTRODUCTION}

Deer are among the few groups of large mammals which have been extensively studied by electrophoretic multilocus investigations to evaluate genetic diversity within and between populations and species (see Hartl and Reimoser, 1988; Hartl et al, 1990a for reviews). However, in contrast to the red deer (Bergmann, 1976; Kleymann, 1976a, b); Bergmann and Moser, 1985; Pemberton et al, 1988; Hartl et al, 1990a, 1991), the fallow deer (Pemberton and Smith, 1985; Hartl et al, 1986; Randi and Apollonio, 1988; Herzog, 1989), the moose (Ryman et al, 1977, 1980, 1981 ; Reuterwall, 1980), the reindeer (Røed et al, 1985; Røed, 1985a, b, 1986, 1987) and the white-tailed deer (Manlove et al, 1975, 1976; Baccus et al, 1977; Johns et al, 1977; Ramsey et al, 1979; Chesser et al, 1982; Smith et al, 1983; Sheffield et al, 1985; Breshears et al, 1988) the factors influencing the amount and distribution of biochemical genetic variation in one of the most abundant European deer species, the roe deer (Capreolus capreolus), are only poorly understood.

The first multilocus investigations to estimate the amount of genetic variability present in roe deer compared with other deer were made by Baccus et al (1983) and, using a more representative sample of individuals, populations and loci, by Hartl and Reimoser (1988). The latter authors detected a comparatively high level of polymorphism and heterozygosity (mean $\bar{P}=17.6 \%, S D=2 \%$; mean expected $\bar{H}=5.4 \%, S D=1.6 \%$ ) and also a comparatively high amount of relative $\left(G_{S T}=8.5 \%\right)$ and absolute (mean Nei's $\left.1972 D=0.0069, S D=0.0049\right)$ genetic differentiation between demes. This result was thought to be due to the ecological strategy of roe deer (within the $r-K$ continuum the roe is considered to be an $r$-strategist : Harrington, 1985; Gossow and Fischer, 1986) and to immigration into the Alpine region from different refugial areas after the last glaciation. With respect to subdivision of the genus Capreolus the existence of several subspecies in the European roe deer as well as the taxonomic status of the Siberian roe deer are under discussion (see Bubenik, 1984; Neuhaus and Schaich, 1985; Groves and Grubb, 1987). On the basis of electrophoretic investigations and other evidence, species rank was postulated for the latter by Markov and Danilkin (1987). 
The aim of the present study was to analyse the amount and distribution of biochemical genetic variation within and among roe deer populations in more detail, and to interpret the results considering the sociobiological and ecological attributes of the roe (an opportunistic species with high ecological plasticity and colonizing ability, but with low migration distances, scattered distribution and population subdivision into local tribes) as described in the literature (Bramley, 1970; Stubbe and Passarge, 1979; Reimoser, 1986; Kurt, 1991). The results were compared to the situation in the red deer, a species of an ecologically and behaviourally opposite type ( $K$-strategist, large and more homogeneous populations, potentially high migration distances : Bubenik, 1984; Harrington, 1985), for which directly comparable electrophoretic data are available (Hartl et al, 1990a). Furthermore, the possible occurrence of different "local races" (Reimoser, 1986) or subspecies of roe deer in the Alpine region (at least north of the main crest) was examined.

\section{MATERIALS AND METHODS}

Tissue samples (liver, kidney) of 239 roe deer from 13 provenances (Fig 1) were collected by local hunters during the hunting seasons of 1988-1989 and 19891990 and stored at $-20^{\circ} \mathrm{C}$. Preparation of tissue extracts, electrophoretic and staining procedures and the genetic interpretation of band-patterns followed routine methods (Hartl and Höger, 1986; Hartl and Reimoser, 1988).

The 27 enzyme systems screened, the presumptive loci and alleles detected and the tissues used are listed in table I.

For completion, data from previously studied roe deer (160 individuals from 7 populations : see Hartl and Reimoser, 1988; and fig 1) are included in this paper. Since the same enzyme systems were screened, the same number of loci was detected, and the various iso- and allozymes were compared for identical electrophoretic mobility using reference samples from the previous study, those data are fully compatible with the results of the present investigation.

At each polymorphic locus the most common allele was designated "100" and variant alleles were assigned according to their relative mobility. The nomenclature is consistent with that already defined by Hartl and Reimoser (1988).

\section{Statistical analysis}

Genetic variation within populations was estimated as the proportion of polymorphic loci $(\bar{P})$, here defined by the $99 \%$ criterion, expected average heterozygosity $\left(\bar{H}\right.$, calculated from allele frequencies) and observed average heterozygosity $\left(\bar{H}_{0}\right.$, calculated from genotypes) according to Ayala (1982).

Relative genetic differentiation among populations $\left(F_{S T}\right.$ in a broader sense : see Slatkin and Barton, 1989) was estimated using Nei's (1977) $F$-statistics, Nei's (1975) $G$-statistics and the method of Weir and Cockerham (1984). Average levels of gene flow among various arrangements of demes were estimated using the relationship between $F_{S T}$ and $N m$ (the number of migrants) described by Slatkin and Barton (1989). We also used Slatkin's (1985) concept of "private alleles", $\bar{p}(1)$, for estimating $N m$ from the formula $\ln (\bar{p}(1))=a \ln (N m)+b$, where values of $a$ and $b$ are -0.505 and -2.440 respectively, for an assumed sample size of individuals 
Table I. Enzyme systems screened (name, abbreviation, EC number) and presumptive gene loci and alleles detected in the roe deer $(\mathrm{L}=$ liver, $\mathrm{K}=$ kidney).

\begin{tabular}{|c|c|c|c|c|}
\hline \multicolumn{3}{|c|}{ Enzyme system } & \multirow{2}{*}{$\begin{aligned} & \text { Loci } \\
& 1(\mathrm{~L})\end{aligned}$} & \multirow{2}{*}{$\begin{array}{r}\text { Alleles } \\
100\end{array}$} \\
\hline Sorbitol dehydrogenase & $\mathrm{SDH}$ & 1.1.1.14 & & \\
\hline Lactate dehydrogenase & $\mathrm{LDH}$ & 1.1.1.27 & $\begin{array}{l}1(\mathrm{~K}) \\
2(\mathrm{~K})\end{array}$ & $\begin{array}{l}100 \\
100,117\end{array}$ \\
\hline Malate dehydrogenase & $\mathrm{MDH}$ & 1.1.1.37 & $\begin{array}{l}1(\mathrm{~K}) \\
2(\mathrm{~K})\end{array}$ & 100 \\
\hline Malic enzyme & ME & 1.1.1.40 & $\begin{array}{l}1(\mathrm{~K}) \\
2(\mathrm{~K})\end{array}$ & $\begin{array}{l}100 \\
\text { unscorable }\end{array}$ \\
\hline Isocitrate dehydrogenase & IDH & 1.1 .1 .42 & $\begin{array}{l}1(\mathrm{~K}) \\
2(\mathrm{~K})\end{array}$ & 100 . 1200,12 \\
\hline 6-Phosphogluconate dehydrogenase & PGD & 1.1.1.44 & $1(\mathrm{~K})$ & 100,71 \\
\hline $\begin{array}{l}\text { Glucose dehydrogenase } \\
\text { Glucose-6-phosphate }\end{array}$ & GDH & 1.1.1.47 & $1(\mathrm{~L})$ & 100 \\
\hline dehydrogenase & GPD & 1.1.1.49 & $1(\mathrm{~K})$ & 100 \\
\hline Xanthine dehydrogenase & $\mathrm{XDH}$ & 1.2 .3 .2 & $1(\mathrm{~L})$ & 100 \\
\hline Glutamate dehydrogenase & GLUD & 1.4 .1 .3 & $1(\mathrm{~L})$ & 100 \\
\hline NADH-diaphorase & DIA & 1.6 .2 .2 & $\begin{array}{l}1(\mathrm{~K}) \\
2(\mathrm{~K})\end{array}$ & $\begin{array}{l}100 \\
100,118\end{array}$ \\
\hline Catalase & CAT & 1.11 .1 .6 & $1(\mathrm{~L})$ & 100 \\
\hline Superoxide dismutase & SOD & 1.15 .1 .1 & $\begin{array}{l}1(\mathrm{~K}) \\
2(\mathrm{~K})\end{array}$ & $\begin{array}{l}100 \\
100\end{array}$ \\
\hline Aspartate aminotransferase & AAT & 2.6.1.1 & $\begin{array}{l}1(\mathrm{~K}) \\
2(\mathrm{~K})\end{array}$ & $\begin{array}{l}100 \\
100\end{array}$ \\
\hline Hexokinase & HK & 2.7.1.1 & $\begin{array}{l}1(\mathrm{~L}) \\
2(\mathrm{~L})\end{array}$ & $\begin{array}{l}100 \\
100\end{array}$ \\
\hline Creatine kinase & CK & 2.7 .3 .2 & $2(\mathrm{~L})$ & 100 \\
\hline Adenylate kinase & $\mathrm{AK}$ & 2.7 .4 .3 & $\begin{array}{l}1(\mathrm{~L}) \\
2(\mathrm{~L})\end{array}$ & $\begin{array}{l}100,250 \\
100\end{array}$ \\
\hline Phosphoglucomutase & PGM & 2.7.5.1 & $\begin{array}{l}1(\mathrm{~K}) \\
2(\mathrm{~K}) \\
3(\mathrm{~K})\end{array}$ & $\begin{array}{l}100,-16 \\
100,113,70 \\
100\end{array}$ \\
\hline Esterases & ES & 3.1 .1 .1 & $E s-d(\mathrm{~K})$ & 100 \\
\hline Alkaline phosphatase & ALP & 3.1 .3 .1 & $1(\mathrm{~K})$ & 100 \\
\hline Acid phosphatase & $\mathrm{ACP}$ & 3.1 .3 .2 & $\begin{array}{l}1(\mathrm{~K}) \\
2(\mathrm{~K})\end{array}$ & $\begin{array}{l}100,200 \\
100\end{array}$ \\
\hline Peptidases & PEP & 3.4 .11 & $\begin{array}{l}1(\mathrm{~K}) \\
2(\mathrm{~K})\end{array}$ & $\begin{array}{l}100 \\
100,115,107\end{array}$ \\
\hline Aminoacydase-1 & $\mathrm{ACY}-1$ & 3.5 .1 .14 & $1(\mathrm{~K})$ & 100 \\
\hline Adenosine deaminase & ADA & 3.5 .4 .4 & $1(\mathrm{~L})$ & 100 \\
\hline Fumarate hydratase & $\mathrm{FH}$ & 4.2.1.2 & $1(\mathrm{~L})$ & 100 \\
\hline Mannosephosphate isomerase & MPI & 5.3 .1 .8 & $1(\mathrm{~K})$ & $100,120,130$ \\
\hline Glucosephosphate isomerase & GPI & 5.3 .1 .9 & $\begin{array}{l}1(\mathrm{~K}) \\
2(\mathrm{~K})\end{array}$ & $\begin{array}{l}100,300,500 \\
100\end{array}$ \\
\hline
\end{tabular}

per deme of 25. In samples deviating considerably from this size, the correction suggested by Slatkin (1985) and Barton and Slatkin (1986) was applied. In order to characterize the amount of gene flow between populations we further used Slatkin's 


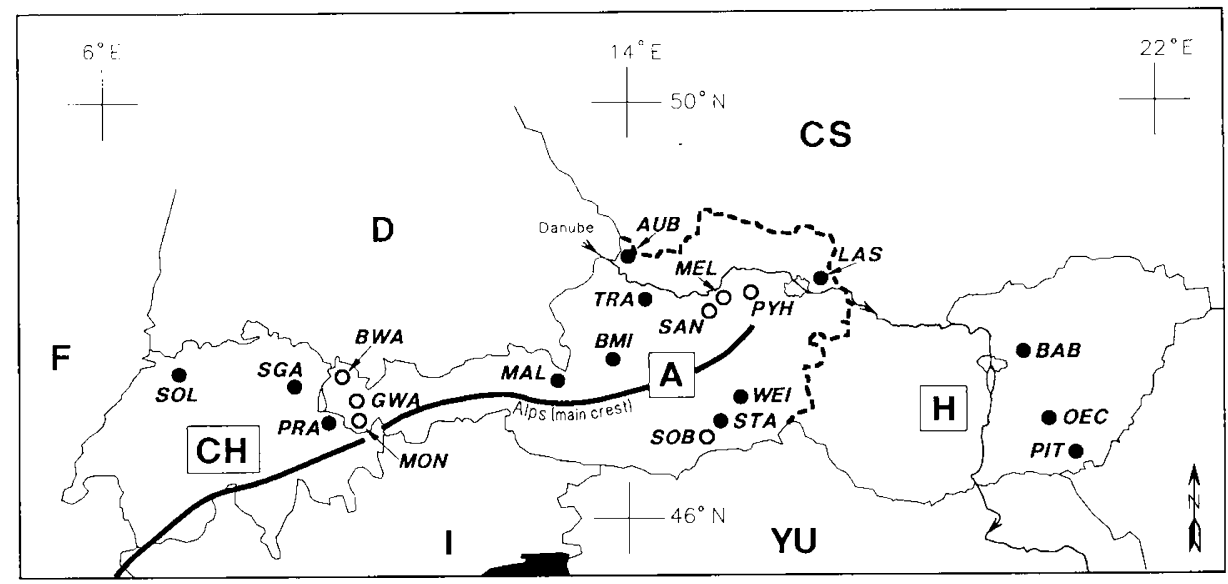

Fig 1. Geographic location of the roe deer provenances studied. Switzerland $(\mathrm{CH}): \mathrm{SOL}=$ Solothurn, SGA = St Gallen, PRA = Prättigau. Austria $:$ BWA = Bregenzer Wald, GWA $=$ Großes Walsertal, MON = Montafon, MAL = Maria Alm, BMI = Bad Mitterndorf, TRA $=$ Traun, $\mathrm{AUB}=$ Auberg, SAN $=$ St Anton $/ \mathrm{J}, \mathrm{MEL}=$ Melk, PYH $=$ Phyra, LAS $=$ Lassee, $\mathrm{WEI}=$ Weiz, STA $=$ Stainz, $\mathrm{SOB}=$ Soboth. Hungary $: \mathrm{BAB}=$ Babat, OEC $=$ Öcsöd, PIT = Pitvaros. Dashed line : border completely fenced from the late 1940 s to the late 1980s. Populations marked by circles instead of dots were already analysed by Hartl and Reimoser (1988).

(1981) concept of the "conditional average frequency" of an allele $(\bar{p}(i))$, which is defined to be its average frequency over those samples in which it is present (Barton and Slatkin, 1986).

Absolute genetic divergence between populations was calculated using several genetic distance measures as compiled by Rogers (1986). To examine biochemical genetic relationships among the roe deer samples studied, dendrograms were constructed by various methods (rooted and unrooted Fitch-Margoliash tree, CavalliSforza-Edwards tree, Wagner network, UPGMA, maximum parsimony method; see Hartl et al, 1990b) using the PHYLIP-programme package of Felsenstein (see Felsenstein, 1985). To check the influence of sample size and the composition of genetic loci chosen, the statistical methods of bootstrap and jacknife were applied (see Hartl et al, 1990a).

\section{RESULTS}

Screening of 27 enzyme systems representing a total of 41 putative structural loci revealed polymorphism in the following 12 isoenzymes : LDH-2, MDH-2, IDH-2, PGD, DIA-2, AK-1, PGM-1, PGM-2, ACP-1, PEP-2, MPI, and GPI-1. In some cases (LDH-2, DIA-2, AK-1, PGM-1, PGM-2, ACP-1, PEP-2, MPI) polymorphism was previously described by Hartl and Reimoser (1988). Also ME-2 was slightly polymorphic in previous studies, but since this isoenzyme was not consistently scorable in the present investigation the corresponding locus ( $M e-2)$ was omitted 
from calculations of genetic variability and differentiation, reducing the total set of loci considered to 40 . In all cases heterozygote band-patterns were consistent with the known quaternary structure of the enzymes concerned (Darnall and Klotz, 1975; Harris and Hopkinson, 1976; Harris, 1980). The monomorphic loci can be seen in table I. Unfortunately, linkage analyses of enzyme loci are not available in roe deer. The most closely related species studied in this respect is the sheep (Ovis ammon), where, as far as they were examined, the loci polymorphic in the roe deer are situated on different chromosomes (O'Brien, 1987).

For the polymorphic loci found, allele frequencies detected in each roe deer population are listed in table II. Single locus heterozygosities, average heterozygosities and the proportions of loci polymorphic are listed in table III. With the exception of $A k-1$ and $P e p-2$ in SOL, and Pgm-2 and $M p i$ in GWA the genotypes in none of the samples deviated significantly from the Hardy-Weinberg equilibrium.

The average frequency of private alleles $(\bar{p}(1))$ in all populations was 0.099 , and the number of migrating individuals per generation $(N \mathrm{~m})$, corrected for an average sample size of 20 was 1 (0.971). Since the overall number of private alleles is small, $\mathrm{Nm}$ was recalculated for 3 subsamples of populations. In the "western group" (SOL, SGA, PRA, MON, BWA, GWA, MAL) $\bar{p}(1)$ was 7.75 and $N m$ (for $n=22.7$ ) was 8.52 , in the "central group" (AUB, BMI, TRA, SAN, MEL, PYH) no private alleles occurred, and in the "eastern group" (WEI, STA, SOB, LAS, BAB, OEC, PIT) $\bar{p}(1)$ was 0.141 and $N m$ (for $n=16.1$ ) was 0.60 .

Since in large mammals the numbers of private alleles seem to be generally rather small, which reduces the reliability of the method, the conditional average frequency $(\bar{p}(i))$ for all alleles was plotted against $i / d$, where $i$ is the number of samples containing a particular allele and $d$ is the total number of samples studied (Slatkin, 1981). This method does not permit a calculation of $N m$, but it gives an overall picture of the distribution of alleles among populations in relation to their frequencies. As shown in figure 2, the number of populations in which an allele is present ("occupancy number"; Slatkin, 1981) increases more constantly with an increasing average frequency of the respective allele in the red deer than in the roe.

Nei's (1975) $G_{S T}$ among all populations studied was $0.126\left(H_{S}=0.049\right.$, $\left.H_{T}=0.056, D_{S T}=0.007\right)$, Nei's $(1977) F_{S T}$ was 0.110 (0.083 when corrected for sample sizes; Nei, 1987), and Weir and Cockerham's (1984) $F_{S T}$ was 0.099 . Our data show that the various estimators for relative gene diversity between populations yield results of the same order of magnitude, which is to be expected due to the same underlying model. In order to test which of the 3 assemblages of roe deer provenances (as defined above) shows the highest amount of gene diversity between populations, $G_{S T}$ was recalculated for each of them. Nei's $G_{S T}$ between populations of the "western group" was 0.086 , the "central group" 0.060 , and the "eastern group" 0.130 .

From those $G_{S T}$-values $N m$, estimated using Wright's formula for the infinite island model (Slatkin and Barton, 1989), was 1.73 (all populations), 2.66, 3.92 and 1.67 , respectively.

Pairwise absolute genetic distances, corrected for small sample sizes (Nei, 1978), showed a mean value of $D=0.0064$ (SD 0.004 7) and a corresponding mean value of $I=0.9937$. 


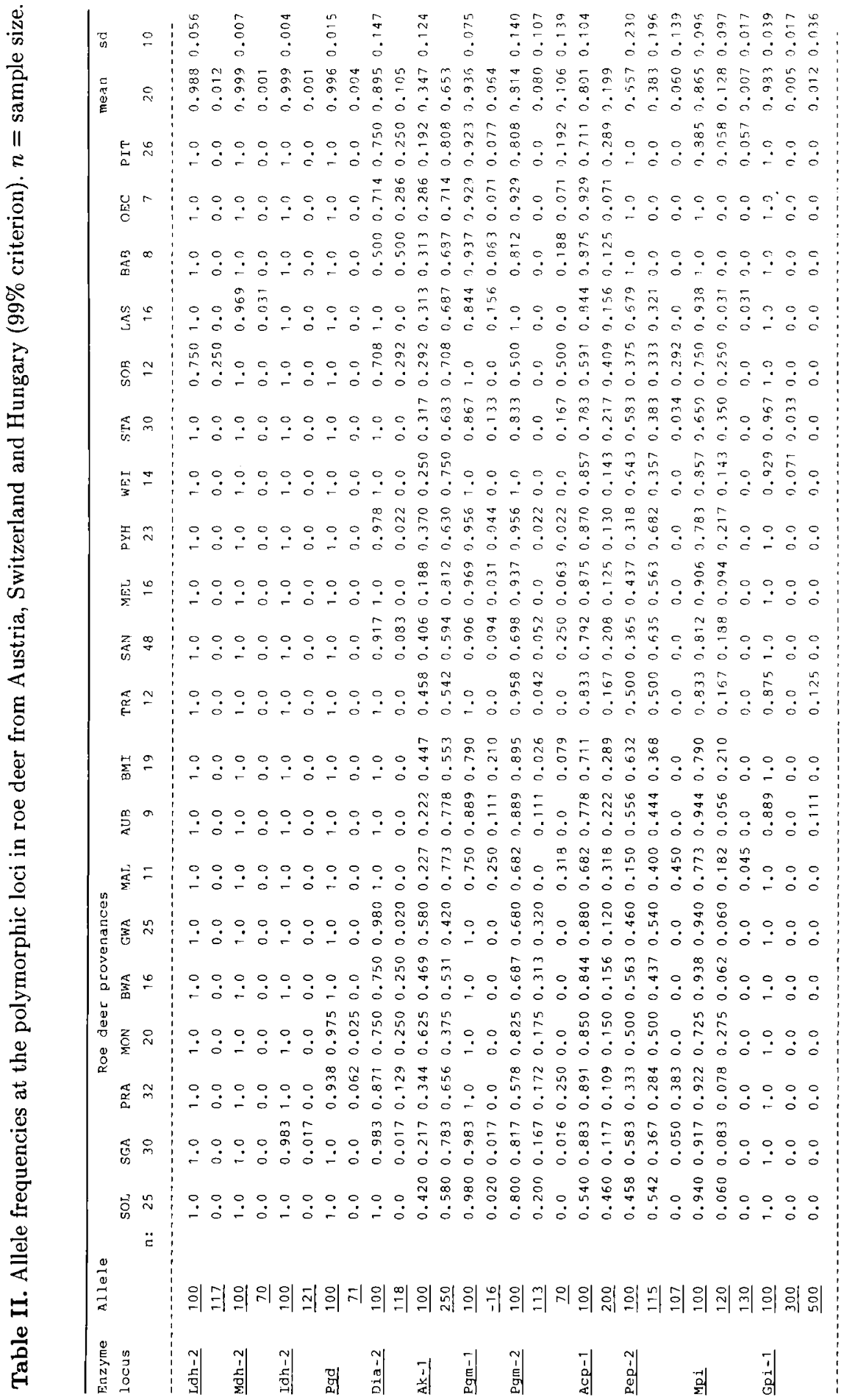




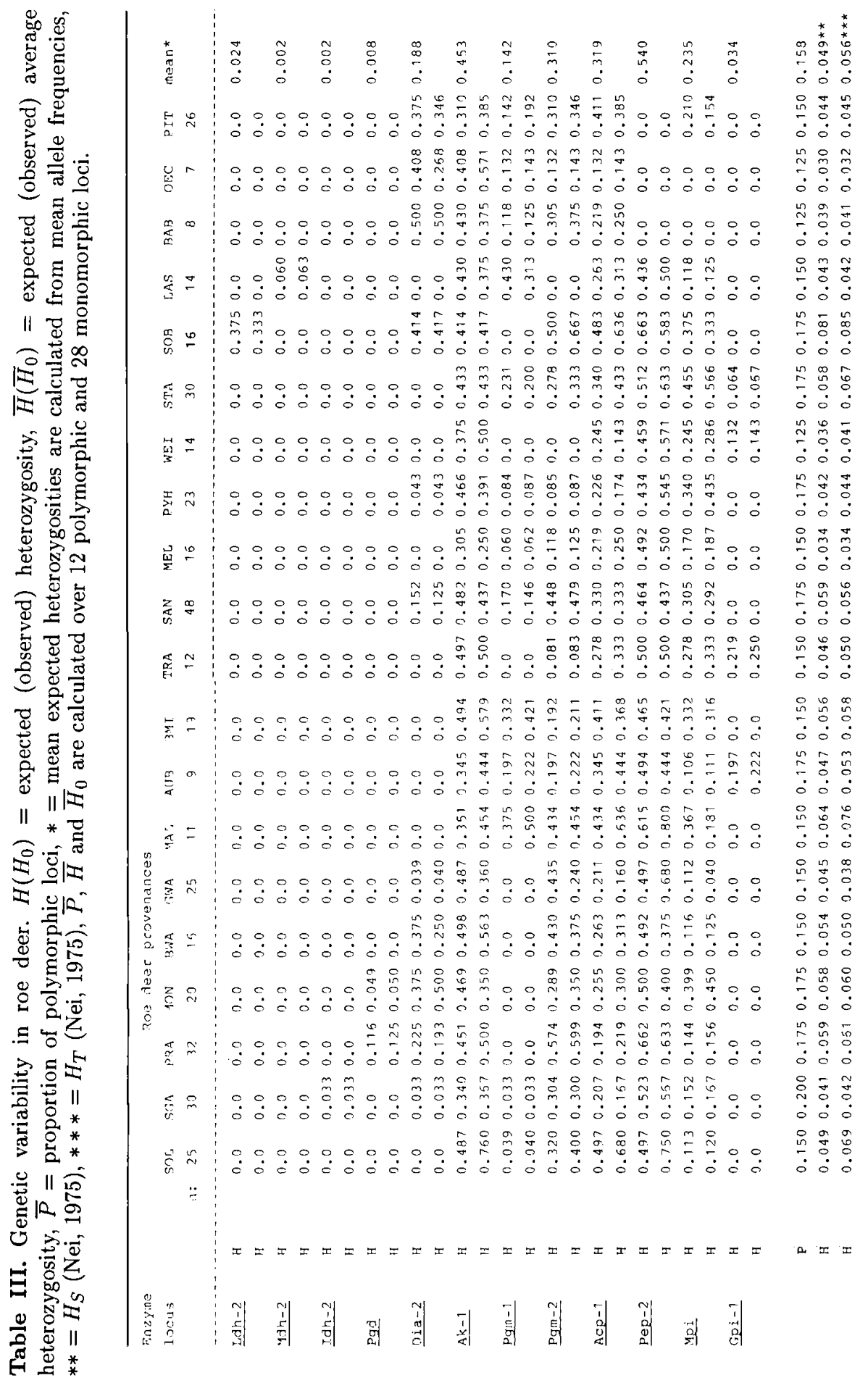




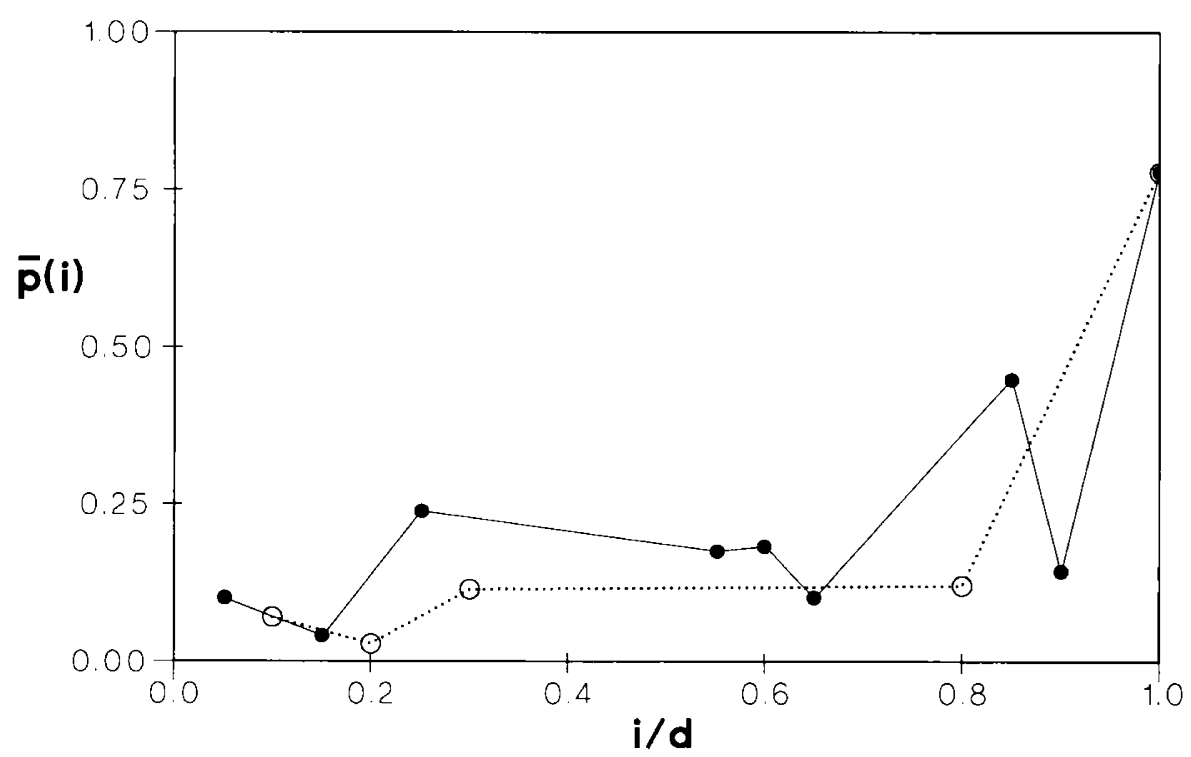

Fig 2. Conditional average allele frequencies $\bar{p}(i)$ for roe deer (solid line) and red deer (dotted line) according to Slatkin (1981). $d=$ No of locations sampled (20 in the roe, 10 in the red).

Genetic relationships among the roe deer populations studied are shown in a rooted (fig 3 ) and an unrooted (fig 4) dendogram. The stability of clusters with respect to the influences of sample sizes and the composition of genetic loci is demonstrated in a bootstrap (fig 5) and a jackknife (fig 6) consensus tree.

\section{DISCUSSION}

\section{Gene diversity, mithin populations}

With a $\bar{P} t$ (total proportion of polymorphic loci for the species) of $30 \%$, amean $\bar{P}$ of $15.8 \%$ (SD 2\%) and a mean expected $\bar{H}$ of $4.9 \%$ (SD 1.2\%) the amount of genetic variation in roe deer detected in the present study is somewhat lower than that described in the white-tailed deer $(\bar{P} t=31.6 \%, \bar{P}=16.1 \%, \bar{H}=6.2 \%$; Sheffield et $a l, 1985)$, similar to that in the reindeer $(\bar{P} t=25.7 \%, \bar{P}=16.0 \%, \bar{H}=4.9 \%$; Røed, 1986), but higher than that in the red $\operatorname{deer}(\bar{P} t=20.6 \%, \bar{P}=11.5 \%, \bar{H}=3.5 \%$; Hartl et al, 1990a), the fallow deer $(\bar{P} t=2.0 \%, \bar{P}=2.0 \%, \bar{H}=0.6 \%$; Randi and Apollonio, (1988) and the moose $(\bar{P} t=21.7 \%, \bar{P}=9.4 \%, \bar{H}=2.0 \%$; Ryman et al, 1980). (For each species only one representative study is cited here; further data are presented in Hartl et al, 1990a, table IV.) Thus, previous results suggesting that the roe deer is among the genetically most variable deer species yet studied (Hartl and Reimoser, 1988) are confirmed. A number of hypotheses attempting to 


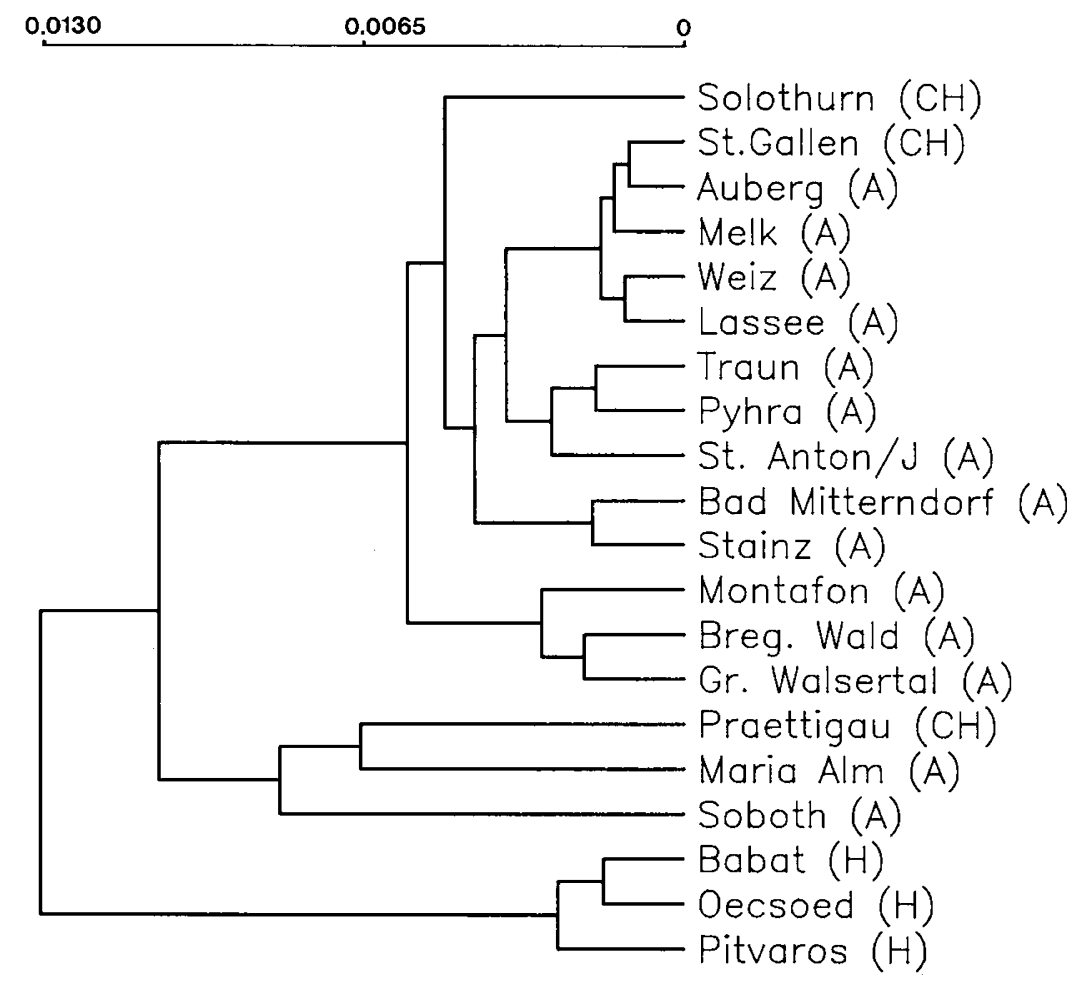

Fig 3. Rooted dendrogram, showing genetic relationships among the roe deer populations studied (UPGMA/D: Nei, 1972). When Nei's (1978) $D$ was used, the topology of the tree remained essentially the same (also other distance algorithms did not patterns different enough to alter the conclusions of the paper).

explain differences in biochemical-genetic variation among populations, species or higher taxa are weakened or corroborated by our data :

- In contrast to the predictions of the "environmental grain" hypothesis (Selander and Kaufman, 1973; Cameron and Vyse, 1978), large mammals are not generally genetically less variable than small mammals (Baccus et al (1983) give a mean $\bar{P}$ of $12 \%$ and a mean $\bar{H}$ of $3.3 \%$ for 25 species of small non fossorial mammals. Nevo et al (1984) give a mean $\bar{P}$ of $19.1 \%$ and $\bar{H}$ of $4.1 \%$ for 184 species of mammals, most of them being rodents and insectivores).

- In contrast to the predictions of the "pleistocene glaciation" hypothesis proposed by Sage and Wolff (1986), mammals inhabiting the northern hemisphere are not generally genetically less variable (because of fluctuations in population sizes in the areas affected by glaciation) than those occurring in more southern regions. From their data cited, a mean $\bar{H}$ of $1.4 \%$ (SD 1.8\%) can be calculated for 16 "northern ", and a mean $\bar{H}$ of $\approx 9 \%$ in 32 "southern" species (in the latter, not all $\bar{H}$ values are given separately for each species, preventing an exact calculation of mean $\bar{H}$ ). At least for the "northern" species they present $\bar{H}$-values in cervid, bovid and mustelid 


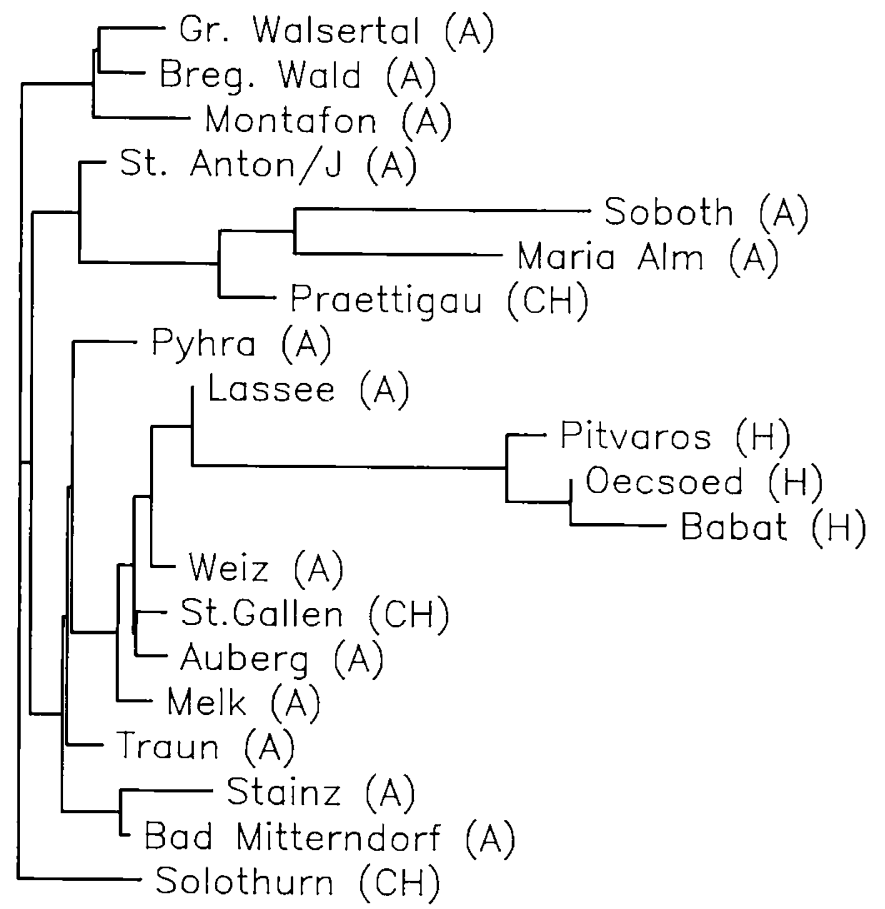

Fig 4. Unrooted dendrogram, showing genetic relationships among the roe deer populations studied (Fitch-Margoliash tree/D : Nei, 1972).

species, which are, in most cases, completely outdated (see Hartl et al, 1988, 1990a; Hartl, 1990a, for reviews).

- Results of Nevo $(1983,1988)$ and Nevo et al (1984) are supported, according to which primitive and generalist species and those with broader geographic, climatic and habitat spectra harbor more genetic variation than their opposite counterparts (in mammals : mean $\bar{H}$ (specialists) $=3.2 \%$ (SD 2.4\%, 71 species), mean $\bar{H}$ $($ generalists $)=5.4 \%(\mathrm{SD} 4.6 \%, 51$ species $))$.

One of the most important problems in the comparison of biochemical-genetic variation between different studies is the very unequal evolutionary rate among proteins (see eg Nei, 1987; Hartl, 1990b, Hartl et al, 1990b). Therefore, unless much the same set of enzymes is examined in all taxa concerned, genetic diversity may be seriously under- or overestimated.

In this respect our data on roe deer are directly comparable to those on red deer obtained by Hartl et al (1990a). The numbers of populations and individuals investigated are similar. Half of the isoenzyme loci polymorphic in roe deer showed allelic variation also in red deer, $A c p-1$ and $L d h$-2 to a similar, Idh-2, Pgm-2, Mpi, and $G p i-1$ to a very different extent. The ratio between ubiquitous and scattered polymorphisms is the same $(\approx 50: 50)$ in both species. $\bar{P} t, \bar{P}$ and $\bar{H}$, however, although showing almost the same ratio between the different indices of variation, are all somewhat lower in red deer. 


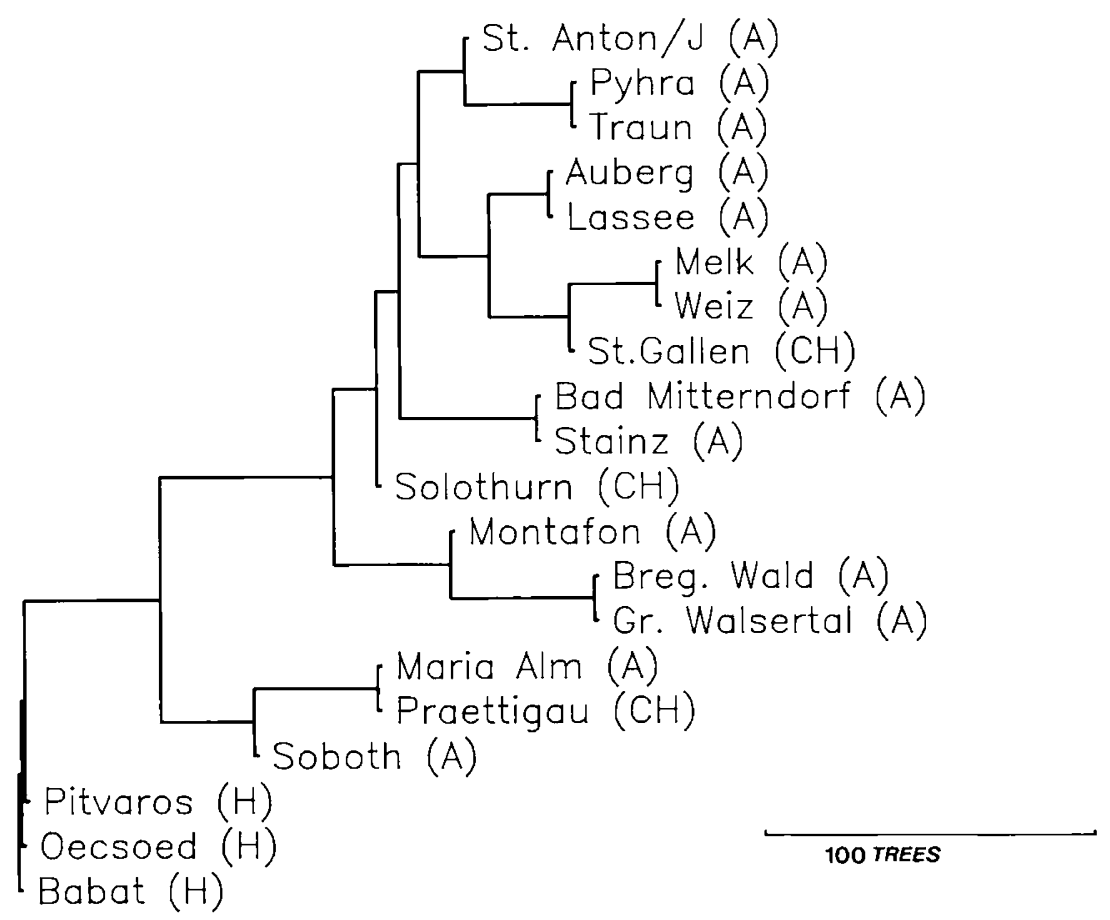

Fig 5. Bootstrap consensus tree $(D:$ Nei, 1972), showing stability of clusters in relation to sample sizes of individuals.

\section{Gene diversity among populations}

Using the private allele method of Slatkin (1985), no marked differences in $\mathrm{Nm}$, the number of migrants per generation, could be detected between the roe deer $(N m=1)$ and the red deer $(N m=1.28)$, which is probably due to the very low number of private alleles occurring in both species. The plot of $\bar{p}(i)$ against $i / d$ (fig 2), however, suggests a little more population subdivision in the former than in the latter species. This difference becomes more prominent when Nei's (1975) $G_{S T}$ of $12.6 \%$ in the roe deer versus $7.9 \%$ among free-ranging red deer populations (Hartl et al, 1990a) is considered. Here the comparison of the estimated number of migrating individuals (1.7 vs 2.9) reflects more clearly the greater migration potential of the red deer. Regarding the estimation of $N m$ from $F_{S T}$ it must be stated that a stepping stone model of population structure, taking into account the hypothesis that gene flow is more likely among neighbouring demes, would reflect the situation in deer more accurately than the island model, according to which gene flow can occur with equal probability among all populations (Lande and Barrowclough, 1987). However, as stated by Slatkin (1987), besides his own method, the latter model is presently the only one to be applied to empirical data. Also when the total number of populations studied in the roe and the red deer is subdivided, there is a difference in $G_{S T}$-values between both species. 


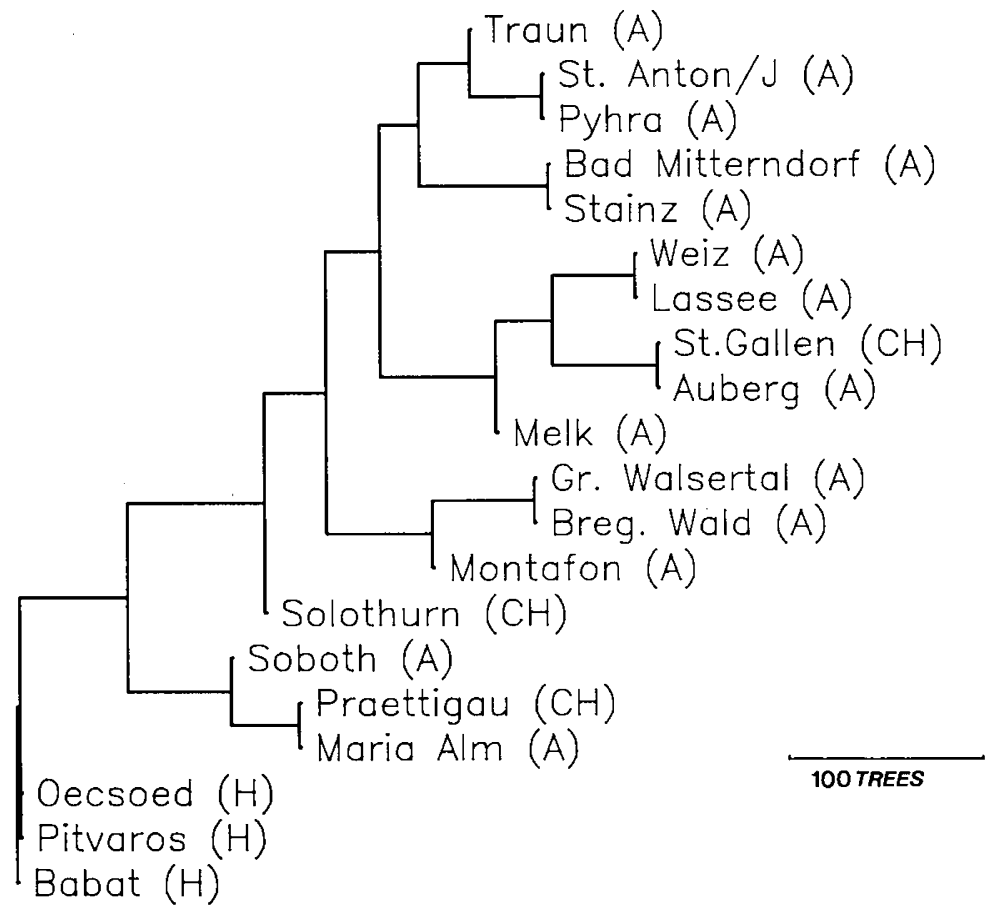

Fig 6. Jackknife consensus tree $(D:$ Nei, 1972), showing stability of clusters in relation to the composition of gene loci sampled.

However, intraspecific differences in $G_{S T}$ between subsamples of populations are more prominent in the roe deer ("western group" $=8.6 \%$; "central group" = $6 \% ;($ eastern group $)=13 \%)$ than in the red $(5.4 \%$ among Hungarian and $5.6 \%$ among western Austrian and French populations, respectively; calculated from Hartl et al, 1990a). Interspecific differences in gene diversity between populations are less apparent when Nei's (1) or Weir and Cockerham's (2) $F$-statistics are used $(1=0.110,1$ corr $=0.083,2=0.099$ in the roe deer $; 1=0.098,1$ corr $=0.075$, $2=0.011$ in the red deer). Altogether, these results suggest that relative differentiation among populations is rather similar in both species and $G_{S T}$ may give an overestimation, because it does not contain a correction for sample sizes of populations or individuals (Slatkin and Barton, 1989). It must, however, be considered that the red deer populations sampled cover a larger geographic range than those of the roe deer and therefore a comparison of $\vec{p}(1), G_{S T}$, or $F_{S T}$-values may be biased towards an overestimation of relative differentiation in this species (Hartl et $a l, 1990 \mathrm{a})$.

\section{Genetic distances and geographical distribution}

If, as pointed out by Slatkin (1987), $N m$ is $>1$, gene flow will prevent a substantial genetic differentiation between populations. Nei's (1978) genetic distances between 
the roe deer populations studied range from $0-0.0226$. The latter value is of a magnitude separating subspecies of red deer (Dratch and Gyllensten, 1985). If an uncorrected $D$ (Nei, 1972) were used (as Dratch and Gyllensten did), the maximum genetic distance between roe deer populations would be even larger $(D=0.0256)$. Overall, the distances between the Hungarian and all other roe deer populations (mean $D=0.0112$, SD 0.0041 ) are much higher than those among populations without the Hungarian samples (mean $D=0.0047 \mathrm{SD} 0.0034$ ). This result suggests that a separate subspecies of Capreolus capreolus is developing in Hungary.

Also when relative genetic differentiation is considered, apart from the Soboth population, the Hungarian provenances contribute most to the high $G_{S T}$-value (13\%) found in the "eastern cluster". They are also far apart from the other populations in the rooted (fig 3 ) and unrooted (fig 4) dendrograms and the stable position of their cluster is confirmed by the bootstrap (fig 5) and the jackknife (fig 6) consensus trees. Because of the completely fenced border between Austria and its neighbouring countries to the East (Hungary, Czechoslovakia) human influence may be responsible for the high genetic distance between the Hungarian and all other populations studied. Other more separated populations are Soboth, Prättigau and Maria Alm, showing even a larger average distance to all other demes than those from Hungary when distance algorithms other than Nei's are used. With respect to neighbouring populations in the south-SOB, the southeastPRA (separated from BWA, GWA and MON by mountains), or the north-MAL (separated from BMI by mountains), they are situated in marginal positions of the study area. Therefore, it cannot be determined whether their large genetic distances - due, for example, to the high frequency of a rare allele at the Pgm-2 and the $P e p$-2 locus - are caused by an introgression from areas not included in the present study or by a loss of these alleles, which were formerly present in all roe deer populations studied. The genetic distances among the remaining roe deer demes are typical for local populations. Their positions in the dendrograms fit quite well to their geographic distribution in several cases (minor deviations may be due to partially very similar genetic distances), but look quite unexpected in others (eg St Gallen). When the distribution of the main polymorphisms is examined, those in AK-1, ACP-1, PEP-2 (2 main allozymes) and MPI (except for Hungary) are quite homogeneous, whereas those in DIA-2, PGM-1, and PGM-2 are scattered. From a methodological point of view it could be argued that the ratio between the number of allelic markers and the populations studied is too low to produce reliable dendrograms. We therefore pooled the 20 samples in various combinations according to geographical criteria, to construct dendrograms using smaller numbers of populations. However, in neither case was the topology of the dendrograms fully consistent with the geographical distribution of the sampling sites, and there seemed to be more information lost than benefit gained from this method. In spite of comparatively few polymorphic markers in relation to the number of provenances and the rather small sample sizes of individuals in relation to very small genetic distances, in the red deer the pattern of genetic differentiation among free-ranging populations agrees better with their geographic positions (Hartl et $a l, 1990 \mathrm{a})$. Therefore, other than methodological factors may be responsible for the partial disagreement between genetic and geographic distances. We put forward the hypothesis that the breeding behaviour and the comparatively patchy distribution 
of roe deer populations (Bramley, 1970; Reimoser, 1986; Kurt, 1991) led towards an increased genetic differentiation among them by the differential loss of one or the other rare allele at enzyme loci polymorphic in all roe deer at the time of the re-invasion of the Alpine region after the last glaciation and/or after bottlenecks caused by overhunting during the last 3 centuries, especially in Switzerland (see Kurt, 1977). On the other hand, it should be noted that the occurrence and distribution of some rare alleles at less polymorphic loci (eg $P g d^{71}$ in Prättigau and Montafon, Gpi-1 $1^{500}$ in Auberg and Traun, Gpi-1 $1^{300}$ in Weiz and Stainz) is in accordance with the geographic neighbourhood of the respective populations, contrasting with the large allele frequency differences at other loci (table II), which are responsible for their unexpected positions in the dendrograms. This could be explained by the assumption that those very rare alleles arose rather recently by mutation, when the geographic distribution of the populations was already very similar to the pattern observed today. A similar case, in which the distribution of very rare alleles displayed the present degree of isolation between demes much better than overall gene diversity, was detected in the red deer by Hartl et al (1991).

Besides past genetic bottlenecks, temporal changes in the composition of roe deer gene pools due to alterations in the social structure of tribes (Kurt, 1991) may also be responsible for an unexpected pattern of genetic similarity among roe deer demes and long-term studies are under-way to investigate such possible short-term changes in allele frequencies in more detail.

In contrast to the results of Beninde (1937), who found the east-west distribution most important to explain differences in morphological characters of the red deer, (apart from the situation in Hungary) the east-west distribution of roe deer demes is not reflected by any cline in allele frequencies or by considerable genetic diversification. The question of a possible north-south differentiation cannot be treated on the basis of the data available, but the Danube and also the Alps seem to be less important for genetic diversification between provenances than previously assumed (see Hartl and Reimoser, 1988).

\section{ACKNOWLEDGMENTS}

The authors are indebted to HG Blankenhorn, C Rühle, A Budde, P Ratti, M Giacometti from Switzerland, R Scherrer, H Stöckl, G Kamsker, F Meran, F Mitter, A Höfler, G Zettel, J Zandl, J Spachinger, A Precht, F Völk, WG Menke from Austria and the local hunters in Hungary for the gift of material and help in the collection of samples. The excellent technical assistance of A Haiden and the graphic work of A Körber are gratefully acknowledged.

\section{REFERENCES}

Ayala FJ (1982) Population and Evolutionary Genetics : A Primer. Benjamin Cummings, Menlo Park, CA, 268 pp

Baccus R, Hillestad HO, Johns PE, Manlove MN, Marchinton RL, Smith MH (1977) Prenatal selection in white-tailed deer. Proc Ann Conf Southeast Assoc Fish Wildl Agencies 31, 173-179 
Baccus R, Ryman N, Smith MH, Reuterwall C, Cameron D (1983) Genetic variability and differentiation of large grazing mammals. J Mammal 64, 109-120 Barton NH, Slatkin M (1986) A quasi-equilibrium theory of the distribution of rare alleles in a subdivided population. Heredity 56, 409-415

Beninde J (1937) Zur Naturgeschichte des Rothirsches. Paul Parey, Hamburg und Berlin, reprinted 1988, $223 \mathrm{pp}$

Bergmann F (1976) Beiträge zur Kenntnis der Infrastrukturen beim Rotwild. Teil II. Erste Versuche zur Klärung der genetischen Struktur von Rotwildpopulationen and Hand von Serumprotein-Polymorphismen. $Z$ Jagdwiss 22, 28-35

Bergmann F, Moser K (1985) Protein-Polymorphismen in Rotwildpopulationen der Bundesrepublik Deutschland. In : Proc 1st Symp on the Genetics of Wild Animals, Giessen. (Herzog A, ed) Justus-Liebig-University, Giessen, 147-157

Bramley PS (1970) Territoriality and reproductive behaviour of roe deer. $J$ Reprod Fertil (Suppl) 11, 43-70

Breshears DD, Smith MH, Cothran EG, Johns PE (1988) Genetic variability in white-tailed deer. Heredity 60, 139-146

Bubenik AB (1984) Ernährung, Verhalten und Umwelt des Schalenwildes. BLVVerlag, Munich, $272 \mathrm{pp}$

Cameron DG, Vyse ER (1978) Heterozygosity in Yellowstone Park elk, Cervus canadensis. Biochem Genet 16, 651-657

Chesser RK, Smith MH, Johns PE, Manlove MN, Straney DO, Baccus R (1982) Spatial, temporal, and age dependent heterozygosity of beta-hemoglobin in whitetailed deer. $J$ Wildl Manage 46, 983-990

Darnall DW, Klotz IM (1975) Subunit constitution of proteins : a table. Arch Biochem Biophys 166, 651-682

Dratch P, Gyllensten U (1985) Genetic differentiation of red deer and North American elk (Wapiti). In : Biology of Deer Production. $R$ Soc NZ Bull 22, $37-40$

Felsenstein J (1985) Confidence limits on phylogenies : an approach using the bootstrap. Evolution 39, 783-791

Gossow H, Fischer A (1986) Alpine Rotwildvorkommen im Konflikt mit verschiedenen Landnutzungs-Interessen. Tagungsbericht, CIC Rotwildtagung Graz, 307-329

Groves CP, Grubb P (1987) Relationships of living deer. In : Biology and Management of the Cervidae (Wemmer C ed) Smithsonian Institution Press, Washington DC, 21-59

Harrington R (1985) Evolution and distribution of the Cervidae. In : Biology of Deer Production. $R$ Soc $N Z$ Bull 22, 3-11

Harris H, Hopkinson DA (1976) Handbook of Enzyme Electrophoresis in Human Genetics. North Holland, Amsterdam

Harris H (1980) The Principles of Human Biochemical Genetics. North Holland, Amsterdam, $554 \mathrm{pp}$

Hartl GB, Höger H (1986) Biochemical variation in purebred and crossbred strains of domestic rabbits (Oryctolagus cuniculus). Genet Res (Camb) 48, 27-34

Hartl GB, Schleger A, Slowak M (1986) Genetic variability in fallow deer, Dama dama L. Anim Genet 17, 335-341 
Hartl GB, Willing R, Grillitsch M, Klansek E (1988) Biochemical variation in Mustelidae : are carnivores genetically less variable than other mammals. Zool Anzeiger 221, 81-90

Hartl GB, Reimoser F (1988) Biochemical variation in roe deer (Capreolus capreolus L.) : are r-strategists among deer genetically less variable than K-strategists? Heredity 60, 221-227

Hartl GB (1990a) Genetische Variabilität beim Mufflon (Ovis ammon musimon). Z Jagdwiss 36, 95-103

Hartl GB (1990b) Genetic variation and biochemical-systematic relationships in Artiodactyla : results and hypotheses on the constancy of molecular evolutionary rates among proteins and taxa. In : Proc 2nd Symp on the Genetics of Wild Animals, Giessen (in press)

Hartl GB, Willing R, Lang G, Klein F, Köller J (1990a) Genetic variability and differentiation in red deer (Cervus elaphus L) of Central Europe. Genet Sel Evol $22,289-306$

Hartl GB, Willing R, Suchentrunk F (1990b) On the biochemical systematics of selected mammalian taxa : empirical comparison of qualitative and quantitative approaches in the evaluation of protein electrophoretic data. Z Zool Syst Evolut forsch 28, 191-216

Hartl GB, Lang G, Klein F, Willing R (1991) Relationships between allozymes, heterozygosity and morphological characters in red deer (Cervus elaphus), and the influence of selective hunting on allele frequency distributions. Heredity 66, 343-350 Herzog S (1989) Genetic polymorphism of transferrin in fallow deer, Cervus dama L. Anim Genet 20, 421-426

Johns PE, Baccus R, Manlove MN, Pinder JE III, Smith MH (1977) Reproductive patterns, productivity and genetic variability in adjacent white-tailed deer populations. Proc Ann Conf Southeast Assoc Fish Wildl Agencies 31, 167-172

Kleymann M (1976a) Beiträge zur Kenntnis der Infrastrukturen beim Rotwild. Teil I. Zur Entwicklung und gegenwärtigen Situation der Rotwildbestände in der Bundesrepublik Deutschland. Z Jagdwiss 22, 20-28

Kleymann M (1976b) Beiträge zur Kenntnis der Infrastrukturen beim Rotwild. Teil III. Zur genetischen Struktur von Rotwildpopulationen anhand von Blutgruppenvergleichsuntersuchungen. $Z$ Jagdwiss 22, 121-134

Kurt F (1977) Wildtiere in der Kulturlandschaft. Rentsch Verlag, Erlenbach-Zürich, $175 \mathrm{pp}$

Kurt F (1991) Das Reh in der Kulturlandschaft-Sozialverhalten und Ökologie eines Anpassers. Paul Parey, Hamburg, 284 pp

Lande R, Barrowclough GF (1987) Effective population size, genetic variation, and their use in population management. In : Viable Populations for Conservation (Soulé ME, ed) Cambridge University Press, Cambridge, 87-123

Manlove MN, Avise JC, Hillestad HO, Ramsey PR, Smith MH, Straney DO (1975) Starch gel electrophoresis for the study of population genetics in white-tailed deer. Proc 29th Ann Conf Southeast Assoc Game Fish Commun 12-15

Manlove MN, Smith MH, Hillestad HO, Fuller SE, Johns PE, Straney DO (1976) Genetic subdivision in a herd of white-tailed deer as demonstrated by spatial shifts in gene frequencies. Proc 30th Ann Conf Southeast Assoc Game Fish Commun 487-492 
Markov G, Danilkin A (1987) Geographic variability of the genus Capreolus Gray 1821. Proc 18th Congr of the Int Union of Game Biol 114-115

Nei M (1972) Genetic distance between populations. Am Nat 106, 283-292

Nei M (1975) Molecular Population Genetics and Evolution. North Holland, Amsterdam $288 \mathrm{pp}$

Nei M (1977) F-statistics and analysis of gene diversity in subdivided populations. Ann Hum Genet 41, 225-233

Nei M (1978) Estimation of average heterozygosity and genetic distance from a small number of individuals. Genetics $89,583-590$

Nei M (1987) Molecular Evolutionary Genetics. Columbia University Press, NY, $512 \mathrm{pp}$

Neuhaus AH, Schaich K (1985) Das Rehwild. Paul Parey, Hamburg, 453 pp

Nevo E (1983) Population genetics and ecology : the interface. In : Evolution from Molecules to Men (Bendall DS, ed) University Press, Cambridge, 287-321

Nevo E, Beiles A, Ben-Shlomo R (1984) The evolutionary significance of genetic diversity : ecological, demographic and life history correlates. In : Evolutionary Dynamics of Genetic Diversity. Lecture Notes in Biomathematics (Mani GS ed) Springer, Berlin, 13-213

Nevo E (1988) Genetic diversity in nature : patterns and theory. In : Evolutionary Biology (Hecht MK, Wallace B ed) Plenum Publ Corp, 23, 217-246

O'Brien SJ (ed) (1987) Genetic Maps 1987 - A Compilation of Linkage and Restriction Maps of Genetically Studied Organisms, Vol 4. Cold Spring Harbor Laboratory, Cold Spring Harbor, $755 \mathrm{p}$

Pemberton JM, Smith RH (1985) Lack of biochemical polymorphism in British fallow deer. Heredity 55, 199-207

Pemberton JM, Albon SD, Guinness FE, Clutton-Brock TH (1988) Genetic variation and juvenile survival in red deer. Evolution 42, 921-934

Ramsey PR, Avise JC, Smith MH, Urbston DF (1979) Biochemical variation and genetic heterogeneity in South Carolina deer populations. $J$ Wildl Manage 43, 136142

Randi E, Apollonio M (1988) Low biochemical variability in European fallow deer (Dama dama L) : natural bottlenecks and the effects of domestication. Heredity 61 , 405-410

Reimoser F (1986) Wechselwirkungen zwischen Waldstruktur, Rehwildverteilung und Rehwildbejagbarkeit in Abhängigkeit von der waldbaulichen Betriebsform. Dissertationen der Universität für Bodenkultur in Wien. VWGÖ, Vienna, 28, 319 pp

Reuterwall C (1980) Genetic variation in a large game species, the moose (Alces alces) : patterns of differentiation and some management implications. PhD Thesis Sundt Offset, ISBN 91-7146-106-X, Stockholm

Røed KH (1985a) Genetic variability in Norwegian semi-domestic reindeer (Rangifer tarandus L). Hereditas 102, 177-184

Røed KH (1985b) Comparison of the genetic variation in Svalbard and Norwegian reindeer. Can J Zool 63, 2038-2042

Røed KH, Soldal AV, Thorisson S (1985) Transferrin variability and founder effect in Iceland reindeer, Rangifer tarandus L. Hereditas 103, 161-164 
Røed KH (1986) Genetic variability in Norwegian wild reindeer (Rangifer tarandus L) Hereditas 104, 293-298

Røed KH (1987) Transferrin variation and body size in reindeer, Rangifer tarandus L. Hereditas 106, 67-71

Rogers JS (1986) Deriving phylogenetic trees from allele frequencies : a comparison of nine genetic distances. Syst Zool 35, 297-310

Ryman N, Beckman G, Bruun-Petersen G, Reuterwall C (1977) Variability of red cell enzymes and genetic implications of management policies in Scandinavian moose (Alces alces). Hereditas 85, 157-162

Ryman N, Reuterwall C, Nygren K, Nygren T (1980) Genetic variation and differentiation in Scandinavian moose (Alces alces) : are large mammals monomorphic? Evolution 34, 1037-1050

Ryman N, Baccus R, Reuterwall C, Smith MH (1981) Effective population size, generation interval, and potential loss of genetic variability in game species under different hunting regimes. Oikos 36, 257-266

Sage RD, Wolff JO (1986) Pleistocene glaciations, fluctuating ranges and low genetic variability in a large mammal (Ovis dalli). Evolution 40, 1092-1095

Selander RK, Kaufman DW (1973) Genic variability and strategies of adaptation in mammals. Proc Natl Acad Sci USA 70, 1875-1877

Sheffield SR, Morgan RP II, Feldhamer GA, Harman DM (1985) Genetic variation in white-tailed deer (Odocoileus virginianus) populations in Western Maryland. J Mammal 66, 243-255

Slatkin M (1981) Estimating levels of gene flow in natural populations. Genetics 99, 323-335

Slatkin M (1985) Rare alleles as indicators of gene flow. Evolution 39, 53-65

Slatkin M (1987) Gene flow and the geographic structure of natural populations. Science 236, 787-792

Slatkin M, Barton NH (1989) A comparison of three indirect methods for estimating average levels of gene flow. Evolution 43, 1349-1368

Smith MH, Chesser RK, Cothran EG, Johns PE (1983) Genetic variability and antler growth in a natural population of white-tailed deer. In : Antler Development in Cervidae (Brown RE, ed) Caesar Kleberg Foundation, Kingsville, 365-387 Stubbe C, Passarge H (1979) Rehwild. VEB Deutscher Landwirtschaftsverlag, Berlin, 432 pp

Weir BS, Cockerham CC (1984) Estimating $F$-statistics for the analysis of population structure. Evolution 38, 1358-1370 